2015

\title{
Trademark Extortion Revisited: A Response to Vogel and Schachter
}

\author{
Kenneth L. Port \\ Mitchell Hamline School of Law, ken.port@mitchellhamline.edu
}

Publication Information

14 Chicago Kent Journal of Intellectual Property 217 (2015)

\section{Repository Citation}

Port, Kenneth L., "Trademark Extortion Revisited: A Response to Vogel and Schachter" (2015). Faculty Scholarship. Paper 266. http://open.mitchellhamline.edu/facsch/266 


\title{
Trademark Extortion Revisited: A Response to Vogel and Schachter
}

\begin{abstract}
Trademark bullying (a.k.a. trademark extortion) is a very controversial notion in trademark litigation in the United States. There, for sure, is a lot of illegitimate trademark infringement happening. Anecdotally, we also know that trademark holders often overstep in the assertion of their otherwise legitimate rights. For the first time, this article documents how large a problem trademark bullying is and how often it happens. Trademark bullying occurs when there is evidence that a trademark holder asserts a non-famous mark against a noncompeting entity on or in connection with goods or services into which the plaintiff has no reasonable expectation of expanding. Trademark bully occurs in at least $5.5 \%$ of the reported cases. This is the same rate that plaintiffs recover any money damages. In the reported cases, trademark bullying is as statistically significant and relevant as cases where the plaintiff recovers money damages. Also, 5.5\% is a floor. Trademark bullying happens at least $5.5 \%$ of the time.
\end{abstract}

As there is no reporting or recording requirement in the United States, trademark bullying, if it happens at all, can only be found if we use deductive reasoning. This article is based on the deductive notion that cases where summary judgment was granted for the defendants are likely to manifest trademark bullying and it is appropriate to label them as such.

In trademark bullying cases, the quality of the plaintiff's claim is declining. This conclusion is supported by regression analysis that indicates that it is accurate to over $99 \%$ certainty. That is, plaintiffs are bringing claims that are less and less likely to succeed on the merits if tried.

As no data (just suppositions) was provided by Vogel and Schachter, it is difficult to claim they are wrong in their analysis. Of course, Rule 11 and the other potential sanctions do exist. With this study, we now know that no Rule 11 sanctions were ever applied to any trademark bullying case. Further, no data is relied on by the various trade organizations (simply outdated dicta from now ancient cases). The data here is the first attempt to prove or disproved trademark bullying. It is provided in the spirit of an academic inquiry. To me, the data here supports the idea that trademark bullying deserves the scrutiny that would be brought to bear if Congress elected to get involved. Clearly, the existing "safeguards" have been proven here to be anything but safe. If nonpracticing entities is a matter worth the time and energy of States and Congress, then trademark bullying is as well as both involve entities which upset natural markets for and with intellectual property.

As such, Congress should act. Congress could go a long way in stopping trademark bullying if it amended Section 1117 of the Lanham to make it explicit that trademark infringement defendants as well as plaintiffs should be awarded its attorney's fees when the opposing party acts egregiously. Attorney's fees should be liberally awarded in cases where the defendant moves for summary judgment and prevails as these cases are the clearest manifestation of trademark bullying.

\section{Keywords}

trademark, bullying, extortion, litigation

\section{Disciplines}

Intellectual Property Law 


\title{
TRADEMARK EXTORTION REVISITED: A RESPONSE TO VOGEL AND SCHACHTER
}

\author{
KENNETH L. PORT
}

\section{INTRODUCTION}

In Volume 103 of the Trademark Reporter, Jason Vogel and Jeremy A. Schachter published an article stating that "concerns regarding trademark bullying do not justify new legislation, and instead there are sufficient safeguards in the form of sanctions, declaratory judgment actions, reverse domain name hijacking provisions, self-help, social media, and Internet publicity to address egregious conduct by trademark counsel." ${ }^{1}$ They claim to agree with the positions of INTA, AIPLA and IPO - that there is nothing that can be learned or gained through Congressional action. They insist, rather, that the problem will resolve itself without having to involve legislation. I respectfully dissent from these views. Mr. Vogel and Mr. Schachter's position, as well as the INTA, AIPLA and IPO, is purely anecdotal and unsupported by any data. I provide here an analysis of real cases based on real data that suggests that trademark bullying is a significant issue. In fact, the pervasiveness of trademark bullying is, statistically, as prevalent as the instances in which money damages are awarded to plaintiffs.

In 2008, I published an article titled Trademark Extortion: The End of Trademark Law $^{2}$ where I discovered and reported alarming trends in trademark litigation. Specifically, the number of cases reaching a trial on the merits was falling drastically since the year 2000. The number of cases where damages were awarded and the amount of damages awarded were similarly falling - in fact, plaintiffs were awarded money damages only $5.5 \%$ of the time. ${ }^{3}$ Treble damages were claimed more often but awarded less frequently and attorney's fees also showed decline. These trends occurred even though the number of cases initially filed continued to increase over time. ${ }^{4}$

1. Jason Vogel \& Jeremy A. Schachter, How Ethics Rules Can Be Used to Address Trademark Bullying, 103 TRADEMARK REP. 503, 518 (2013).

2. Kenneth L. Port, Trademark Extortion: The End of Trademark Law, 65 WASH. \& LEE L. REV. 585 (2008) [hereinafter Port, Extortion].

3. Id. at 612 .

4. See infra Table 1. 
In Trademark Extortion, I argued that this was evidence that trademarks were being used for something other than the assertion of a right. ${ }^{5}$ Rather than reducing transaction costs by promoting business goodwill, trademark litigation tactics - extortion, if you will-were effectively increasing the cost of market entry for third parties. Specifically, the evidence suggested that trademarks were increasingly being used as leverage against non-competing entities in an effort to coerce them into submission of their mark. This tactic serves to broaden the trademark holder's rights and, thereby, increase the likelihood that the mark will become famous. Once famous, competition is no longer relevant where the trademark holder asserts a dilution claim ${ }^{6}$ — a claim only available to famous marks. Conversely, where the mark is not famous, the holder must show that it is in competition with the alleged infringer, has actual plans to be in competition, or that competition is in the zone of natural expansion of the plaintiff's goods or services as a prerequisite to recovery. ${ }^{7}$

The point of Trademark Extortion was to show that trademark holders are using the threat of litigation as an additional vehicle by which they can broaden the scope of their trademark rights. The Constitution and the Lanham Act both contemplate that this broadening will happen through actual use of the mark in commerce. Alarmingly, it seemed to me in 2008 that we were embarking on a new course in trademark law and policy in the United States where rights were determined by litigation rather than by use.

For those suffering the consequences of this conduct, the trade organizations and the United States federal government have been remarkably disobliging. Rather, Vogel and Schachter, as well as the INTA, AIPLA,

5. Port, Extortion, supra note 2, at 633.

6. See Lanham Act § 43(c)(1), 15 U.S.C. § 1125(c)(1) (2012) (stating that injunctive relief is available regardless of the presence or absence of actual or likely confusion) (emphasis added).

7. With this statement, I do not intend here to enter the debate as to the degree of competition that is required (or should be required) for a plaintiff to have standing to file suit or enforce its mark. I am only intending to show that the traditional understanding of trademark jurisprudence was/is to require competition or the likelihood of competition before a case or controversy exists. See, e.g., Leah Chan Grinvald, Shaming Trademark Bullies, 2011 WIS. L. REV. 625, 636-37 (2011). To the extent that American trademark jurisprudence-mostly in the form of academic commentary-diverges from this traditional understanding, it renders the dilution rationale even more irrelevant and, interestingly, further incentivizes trademark holders to engage in bullying conduct because they don't have to show that their mark is famous to enjoin a non-competitor, they only have to show that the mark is distinctive and/or strong. Id. at 638. As I have argued elsewhere, dilution rationale is most easily understood when the traditional view of trademark jurisprudence is followed. Kenneth L. Port, The Congressional Expansion of American Trademark Law: A Civil Law System in the Making, 35 WAKE FOREST L. REV. 827, 831 (2000). That is, dilution rationale should be applied when the parties are not and will not be in competition. Infringement rationale should be applied when the parties are or will be in competition. Practitioners do not make this distinction easy on judges when they claim both infringement and dilution in the same case. Under traditional trademark jurisprudence, infringement and dilution ought to be mutually exclusive and not applicable to the same set of operative facts. Judges do not seem to understand this distinction when they find marks infringed and diluted. 
IPO, and PTO, have joined forces in an effort to convince Congress that nothing should be done. They claim that existing rules, such as Rule 11 and others, are a sufficient response to trademark bullying, if bullying is happening at all. ${ }^{8}$

Yet, not only does trademark law permit trademark bullying to existit requires it. ${ }^{9}$ Trademark holders have a duty to police their marks, as acquiescence to another's use of the same or similar mark on the same or similar goods entitles the junior user to a host of defenses to infringement. ${ }^{10}$ The AIPLA insists that trademark extortion is essentially the exercise of that duty. The proposition that a mark holder has an affirmative duty to police all use of its mark, however, relies on dicta from a case decided over thirty-years ago in 1979. ${ }^{11}$ I submit that much, including trademark law, policy, the economy, the Internet, etc., has changed since 1979 to warrant a different approach even if this reference was not to gratuitous dicta. I attempt to use data, rather than merely supposition, to support my contention that trademark bullying is happening, is happening often, and is significant enough to warrant Congressional action.

Trademark bullying is an actual, measurable harm and it continues to grow. ${ }^{12}$ In fact, as the quality of trademark claims continues to decline, spurious claims increase. ${ }^{13}$ Trademark bullying itself happens as often as a trademark holder is awarded money damages ${ }^{14}$; it is present in at least $5.5 \%$ of all reported trademark cases. ${ }^{15}$ Therefore, trademark bullying is, statistically, as prevalent as money damages in trademark litigation.

8. Vogel, supra note 1, at 505-06.

9. See Ill. High Sch. Ass'n v. GTE Vantage, Inc., 99 F.3d 244, 246 (7th Cir. 1996) (Posner, J.) (“A serious trademark holder is assiduous in endeavoring to convince dictionary editors, magazine and newspaper editors, journalists and columnists, judges, and other lexicographically influential persons to avoid using his trademark to denote anything other than the trademarked good or service."); Cullman Ventures, Inc. v. Columbian Art Works, Inc., 717 F. Supp. 96, 124 (S.D.N.Y. 1989) ("A trademark owner's efforts at policing its trademarks is further proof of the strength of those marks.”).

10. See Seller Agency Council, Inc. v. Kennedy Ctr. for Real Estate Educ., 621 F.3d 981, 988 (9th Cir. 2010) (stating that the defense of acquiescence "limits a party's right to bring suit following an affirmative act by word or deed by the party that conveys implied consent to another"); Roederer v. J. Garcia Carrion, S.A., 569 F.3d 855, 858-59 (8th Cir. 2009) ("Laches is an equitable defense to an action to enforce a trademark. Laches applies when a claimant inexcusably delays in asserts its claim ...”).

11. Proctor and Gamble Co. v. Johnson and Johnson, Inc., 485 F. Supp. 1185, 1207 (S.D.N.Y 1979).

12. See infra, Part III.

13. See infra, Part III.

14. See infra, Part III.

15. See infra, Part III. 
As such, Congress should get involved to legislate a solution. The best solution is to amend Section 1117 of the Lanham Act ${ }^{16}$ to clarify that defendants can obtain reasonable attorney's fees in egregious cases (like bullying) as well as plaintiffs. This would encourage attorneys to take trademark bullying cases and represent defendants. It would also discourage the prosecution of trademark cases that are only meant to harass or raise the cost of market access for defendants with little expectation of success on the merits. Anecdotally, we also know that once represented by competent trademark counsel, trademark bullying cases tend to evaporate. ${ }^{17}$ Congress should get involved to create an income stream for trademark counsel who represent the bullied so that trademark counsel do not have to do it pro bono, if the bullied entity cannot pay.

\section{Definition of Trademark Extortion}

Today, most people refer to what I dubbed trademark extortion ${ }^{18}$ as "trademark bullying." Trademark bullying is a less inflammatory term to describe the same conduct. Trademark extortion, or "bullying," means the use of a non-famous trademark to enjoin (or seek or threaten to enjoin) a non-competing use by a third party.

Some seem to presume that the relative size or capitalization of companies involved in trademark disputes is generally indicative of whether trademark bullying is present. ${ }^{19}$ Although the relative size of a company may make the litigation more or less painful to fund, it does not, by definition, predict bullying. That is, often times, large companies sue small companies or individuals for trademark infringement. Most of the time, these cases are legitimate trademark complaints where the defendant knowingly or (most likely) unknowingly used the plaintiff's mark in commerce in an infringing manner. If our trademark system is legitimate and to be relied upon, we should not interfere with legitimate trademark infringement

16. 15 U.S.C. $§ 1117$ (2008).

17. They evaporate and enter settlement terms that prevents the bullied party from speaking about the terms and conditions of the settlement. What we do know indicates that these terms are often quite positive for the bullied entity including cash payments from the Plaintiffs themselves would brought the claim in the first place.

18. Port, Extortion, supra note 1, at 585.

19. Mark J. Miller, Trademark Wars Escalate and it's all the Web's Fault 5 , 2012 10:01AM), http://www.brandchannel.com/home/post/2012/03/05/Trademark-Wars030512.aspx (quoting noted American trademark law expert Professor Barton Beebe as saying “The big companies will do this to rough up their competitors.”). 
cases. After all, every trademark defendant believes s/he is being bullied; most often, s/he is simply an infringer. ${ }^{20}$

Thus, a more clear and helpful definition of trademark bullying is needed. After researching trademark extortion for the better part of six years, as well as coining the term "trademark extortion," I have come up with the following definition: Trademark Bullying occurs when there is evidence that a trademark holder asserts a non-famous mark against a noncompeting entity on or in connection with goods or services into which the plaintiff has no reasonable expectation of expanding.

A trademark bully is, according to this definition, not the holder of a famous appellation. The Lanham Act allows for the holders of famous marks to broadly assert trademark rights in the name of trademark dilution. ${ }^{21}$ Trademark bullying contemplates a situation where the party asserting the trademark right would likely not prevail if the case were fully litigated because the parties are not competing (and there is no intention of competition in the future); however, if a mark is subject to dilution protection (meaning it is famous), competition becomes irrelevant. ${ }^{22}$ Therefore, by definition, a famous mark cannot be the subject of trademark bullying because a famous mark can be legitimately enforced against even noncompeting entities. ${ }^{23}$

An axiom of American trademark jurisprudence (not dilution justification) has been that one seller of goods should not divert consumers from another. ${ }^{24}$ A long time ago, Learned Hand succinctly articulated the following:

20. In response to Trademark Extortion, some criticized me for seeming to be legitimizing or defending infringing conduct. [Find the Scott Johnston quote] Quite to the contrary, I believe in the rule of law and the value of a predictable, legitimate trademark system. Economic investment, growth and wealth all grow out of meeting economic expectations. To be sure, I am not arguing for something that does not recognize or respect the legitimate assertion of legitimate trademark rights.

21. See Port, Extortion, supra note 2 at 590

22. See id. at $590-91$.

23. 15 U.S.C. § 1125(c)(1) (2012) ("the owner of a famous mark ... shall be entitled to an injunction against another person who ... commences use of a mark or trade name in commerce that is likely to cause dilution by blurring or dilution by tarnishment of the famous mark, regardless of the presence or absence ... of competition ...").

24. See New Kids on the Block v. News America Pub., Inc., 971 F.2d 302, 305 (9th. Cir. 1992) (noting that "the wrong protected against" by traditional trademark law was "[p]reventing products from free-riding on their rivals' marks”); United States v. Hon, 904 F.2d 803, 806 (2d. Cir. 1990) (stating that one purpose of trademark law "protecting the trademark owner's investment in the 
The law of unfair trade comes down very nearly to this - as judges have repeated again and again - that one merchant shall not divert customers from another by representing what he sells as emanating from the second. This has been, and perhaps even more now is, the whole Law and the Prophets on the subject. . . ${ }^{25}$

Paradoxically, there is also the so-called "unrelated goods doctrine."26 Some claim that its existence requires an expanded view of trademark infringement and incentivizes trademark bullying. ${ }^{27}$ This doctrine recognizes that not all infringing conduct is on or in connection with goods or services that are immediately and directly competing. If a mark is strong, the relative range of goods and services on which it may be used grows. That is, the stronger the mark, the larger the range of goods and services for which the mark will be protected. The stronger the mark the more distinctive the mark and the more likely that one or more of the multiple factors will viewed in favor of the plaintiff-namely the likelihood that the plaintiff will bridge the gap between the non-competing goods or services. ${ }^{28}$

Each Circuit has adopted its own, distinct test for trademark infringement analysis. Yet, many of the Circuits' tests are very similar. For instance, five of the eleven Circuit Courts of Appeal tests for trademark ininfringement contain an express element that is, essentially, the likelihood the plaintiff will bridge the gap. Essentially, bridging the gap is the likelihood that the plaintiff will in the future sell a good or service that would more directly compete with the defendant's goods or services. ${ }^{29}$ Trade-

quality of the mark and his product's reputation"); Kroger Co. v. Johnson \& Johnson, 570 F.Supp 1055, 1060 (S.D. Ohio 1983) ([T]o permit a bystander who has spent a minimum of time, money, and effort in developing its product to profit by marketing the identical commodity with a similar name and packaging is contrary to state Congressional purpose of the Lanham Act.”).

25. Yale Elec. Corp. v. Robertson, 26 F.2d 972, 973 (2d Cir. 1928).

26. Aunt Jemima Mills Co. v. Rigney \& Co., 247 F. 407 (2d Cir. 1917), cert. denied, 245 U.S. 672 (1918).

27. Leah Chan Grinvald, Shaming Trademark Bullies, 2011 WISC. L. REV. 625, 636-37 (2011) (Although otherwise a substantively accurate piece, the author does claim that bullying is dependent on the relative size of the two corporations in a trademark dispute. As demonstrated below, the relative size or capitalization of the companies may make the case more or less sympathetic but is not, in itself, a manifestation of bullying conduct).

28. The weakness of relying on the "bridging the gap" element was recent made plain in Robert G. Bone, Taking the Confusion out of "Likelihood of Confusion": Toward a More Sensible Approach to Trademark Infringement, 106 Nw. U. L. REV. 1307, 1340-41 (2012).

29. See Lang v. Retirement Living Publ'g Co., 949 F.2d 576, 582 (2d Cir. 1991) (the perception of consumers affects the likelihood of confusion because if 
mark law is meant to be prospective ${ }^{30}$ and allow the trademark plaintiff's rights to expand over time. This expansion through the so-called related goods doctrine has to be objective and the record has to contain evidence that indicates the plaintiff actually intends such expansion or that the expansion is "natural." "31

The assertion of a mark in a reasonable (or natural) zone of expansion, too, is not bullying. Bullying contemplates enforcing trademark rights beyond the scope of the plaintiff's trademark rights and beyond a reasonable (or natural) expansion of those rights depending upon the strength of the plaintiff's mark. That is, whether or not bullying could or should be dealt with using existing rules regarding professional responsibility and the like, it is an extremely nuanced endeavor requiring an extremely nuanced analysis. We do this serious issue no favor by making bold, across the spectrum claims based on no data.

America is replete with anecdotal stories of trademark bullying where the only logical explanation for the conduct of the plaintiff was that it was engaging in bullying. In addition to the famous examples provided by Vogel and Schachter, some others include the following:

Rob Linden, a business owner that installs blown-in insulation into new homes, adopted the trade name (not the trademark) THERMAL WISE INSULATION as the name of his LLC. Mr. Linden operates solely within the Minneapolis, Minnesota area. Mr. Linden was sued by Questar, Inc. (“Questar”) for allegedly infringing their mark THERM-WISE to describe a rebate program and promotion where, as a regional monopoly in the state of Utah and immediate environs, it encourages people to wisely use energy. ${ }^{32}$ Although Mr. Linden and Quester operate different businesses in different states, Questar is attempting to make Mr. Linden stop using the name of his LLC. ${ }^{33}$

consumers perceive bridging the gap as probable, they are more likely to believe that the junior user's products emanate from the senior user).

30. See Paco Sport, Ltd. v. Paco Rabanne Parfums, 86 F. Supp. 2d 305, 318 (S.D.N.Y. 2000) (citing Hormel Foods Corp. v. Jim Henson Prods, 73 F.3d 497, 504 (2d Cir. 1996)) (the actual probability of bridging the gap is relevant because the trademark law protects, in part, the senior user's interest in being able to expand into a related field in the future).

31. GMA Accessories, Inc. v. Croscill, Inc., No. 06 Civ. 6236 GEL, 2007 WL 766294, *6-7 (S.D.N.Y. Mar. 12, 2007).

32. See QUESTAR GaS, http://www.thermwise.com/ (last visted Sept. 28, 2014). (Lists "home energy plan" and the tag line "If you conserve, you save.")

33. See Questar Gas v. Thermal Wise Insulation, 2:12-cv-00007-DN, (Utah Jan. 4, 2012) (RFC Express), http://www.rfcexpress.com/lawsuits/trademark- 
Lorenzo Borghese and his family were sued by Borghese, Inc. for use of the name BORGHESE in connection with the sale of pet care products. Borghese, Inc. is the assignee of the mark PRINCESS MARCHELLA BORGHESE for use on, or in connection with, cosmetics. ${ }^{34}$ Unless pet care products are a natural extension of cosmetics for women or unless Borghese, Inc. has specific plans to expand into pet care products, this part of the law suit is best characterized as trademark bullying.

A college student in Missouri attempted to fund his education by selling outdoor athletic gear under the appellation SOUTH BUTT, upsetting the manufacturers of North Face. ${ }^{35}$ Similarly, a man in Vermont attempted to register EAT MORE KALE, upsetting the Chick-fil-A corporation in light of its use of the mark EAT MOR CHIKIN (in the form of cows holding up a sign extorting such conduct-an example provided in the Vogel and Schachter article but they excluded the humorous context). ${ }^{36}$

The anecdotes abound. We are told, by people like Vogel and Schachter that these are not important and, ignoring any data that does exist, we should allow the law as it exists deal with these incidents. With this article, however, there is now good data that indicates that, more likely than not, trademark bullying is happening and should be dealt with by Congressional action.

\section{DATA}

Trademark bullying cases have been, heretofore, as elusive and anecdotal. Trademark plaintiffs are free to make claims of infringement, for legitimate or tactical reasons, without having to record or report such claims. Coupled with the vagaries of the requirement that trademark holders police potential infringing uses of their marks, it becomes exceedingly difficult to tell when a case amounts to bullying and when it is legitimate. ${ }^{37}$

lawsuits/utah-district-court/87570/questar-gas-v-thermal-wise-insulation/summary/ (last updated Jan. 4, 2012).

34. Christine Haughney, Borghese v. Borghese: Battle for a Royal Name, NY Times, June 15, 2013, http://www.nytimes.com/2013/06/16/business/borghese-vborghese-battle-for-a-royal-name.html?pagewanted=all\&_r $=0$ (last visited on February 11, 2015).

35. See Jim Salter, North Face settles lawsuit against South Butt, NBC News (April 11, 2010), http://www.nbcnews.com/id/36334733/ns/businessconsumer_news/t/north-face-settles-lawsuit-against-south-butt/\#.UeyH9D5VSnw.

36. Chick-fil-A Fails To Stop 'Eat More Kale' Trademark, Forbes Magazine, Dec. 15, 2014, http://www.forbes.com/sites/christinapark/2014/12/15/chick-fil-afails-to-stop-eat-more-kale-trademark/ (last visited on February 11, 2015). 37. See Vogel, supra note 8 at 1. 
Until now, there have been no statistical attempts to show that bullying is real and/or and how frequently it happens. The data below suggests that it is very real and happens at same rate that trademark plaintiffs recover money damages.

To test for trademark bullying, I looked at all reported cases since the inception of the Lanham Act where the defendant moved for summary judgment. I used the database that I built in my original article Trademark Extortion. ${ }^{38}$ That database consists of every reported case that was dispositively terminated in America relying on the Lanham Act. The database consists of all reported cases from July 1, 1947 through 2011. I harvested from that database, all cases where the defendant moved for summary judgment and prevailed. ${ }^{39}$

General legal literature supports the notion that defendants are very unlikely to prevail in a motion for summary judgment in general subject matter jurisdiction. ${ }^{40}$ In fact, in general, defendants prevail in their motions for summary judgment only $4 \%$ of the time. ${ }^{41}$ Trademark defendants, however, in the last decade prevailed at $5.5 \%$ of the time or slight more than general litigation. Further data would have to be collected and analyzed to determine if this difference is due to trademark bullying activity which may not be present or adequately represented in the general data.

Summary judgments for defendants are a good place to test the prevalence of trademark bullying. Usually, discovery has closed. ${ }^{42}$ The judge looks at all of the plaintiff's evidence and, drawing all reasonable references in favor of the plaintiff, concludes that there are no material facts in dispute and that the defendant is entitled to a judgment as a matter of law..$^{43}$ This is and should be a rare event. For the judge to grant a motion for summary judgment brought by the defendant, the judge is interfering with the plaintiff's chance to be heard, the chance to get a case before a jury, and a chance that, though not strong, it still might prevail. ${ }^{44}$ For the court to

38. See Port, Extortion, supra note 2 at 611-21

39. For a more detailed description of the methodology of this study, See infra Part IV.

40. See Joe Cecil \& George Cort, Report on Summ. J. Prac. Across Dists. with Variations in L. R. at 17, Table 12 (FJC Aug. 13, 2008), (re-analyzing 2006 data showing a summary judgment rate of just over $4 \%$ )

41. Id.

42. TBMP § 528.02 (2011).

43. See CMM. Cable Rep., Inc. v. Ocean Coast Props., Inc., 97 F.3d 1504, 1512-13(1st Cir. 1996).

44. Panavision Int'l L.P. v. Toeppen, 945 F.Supp. 1296, 1301 (C.D. Cal. 1996) ("summary judgment is disfavored in trademark cases because of the inherently factual nature of most trademark disputes.”). 
grant a summary judgment motion brought by the defendant, the plaintiff's case must, by definition, be extremely weak. These are the cases that most likely encompass instances of trademark bullying.

There are some alarming trends when looking at the number of cases in the last 60 years broken-down by decade.

Table 1:

\begin{tabular}{|c|c|c|c|c|}
\hline ade ${ }^{\text {Dec- }}$ & $\begin{array}{l}\text { Sum- } \\
\text { mary Judg- } \\
\text { ment Granted } \\
\text { to Defendant }\end{array}$ & $\begin{array}{l}\text { Aver- } \\
\text { age strength } \\
\text { of case }\end{array}$ & $\begin{array}{l}\text { Percent- } \\
\text { age of all } \\
\text { reported cases }\end{array}$ & \begin{tabular}{l}
\multicolumn{1}{c}{ Total } \\
number of \\
all reported \\
cases
\end{tabular} \\
\hline $1959^{1950-}$ & 4 & 1.87 & $1.4 \%$ & 270 \\
\hline 1969 & 5 & 1.92 & $1.9 \%$ & 251 \\
\hline $19799^{1970-}$ & 14 & 1.84 & $4.5 \%$ & 309 \\
\hline $1989^{1980-}$ & 16 & 1.49 & $2.5 \%$ & 636 \\
\hline $1999^{1990-}$ & 40 & 1.41 & $5.8 \%$ & 682 \\
\hline $2009^{2000-}$ & 40 & 1.33 & $5.5 \%$ & 731 \\
\hline
\end{tabular}

The first obvious trend is that the raw incidents of cases where the defendant is granted a summary judgment have increased. They have not only increased in real terms, they have increased in relative terms. In the decade ending in 1969, there were a total of 251 cases in the database. In the decade ending in 2009, there were 731 cases. In the decade ending in 1969 , this number accounted for $1.9 \%$ of the cases; by 2009 , this number accounted for $5.5 \%$ of the cases. That is, in relative terms, the number of cases where summary judgment was granted to the defendant increased 8times in 50 years while the rate of increase of all cases increased only by 2.91-times. ${ }^{45}$

45. Further data need must be collected and analyzed to determine the significance of the fact that incidents of trademark bullying actually may be ameliorating slightly over time. In the decade prior to the last decade, bullying claims peaked at $5.8 \%$ of reported cases. Although this was the same raw number of cases (40) that manifest bullying characteristics, the $5.5 \%$ figure cited throughout this article is a slight decrease from the previous peak. That is, this is the only piece of data in my study that indicates Vogel and Schachter may be correct. If this problem is going 
Second, the average strength of the case dropped significantly during the same time frame. From a high of 1.9 out of 3 for a quality score in the decade that ended in 1969, it reached a low of 1.33 by the decade that ended in 2009. That is, in the same 50 years, the quality of the plaintiff's claim dropped by more than $71 \%$.

Most significantly, the rate of summary judgment being awarded to the defendant is now 5.5\% of reported cases. For those that feel trademark bullying is insignificant, marginal, and should not be studied or discussed further, this is an important finding. Trademark bullying happens at the same rate that money damages are awarded to the plaintiff. Statistically speaking, money damages are as relevant as trademark bullying.

More significant still, this data is quite well supported by statistical analysis.

\section{A. Regression Analysis}

\section{Strength of Claim}

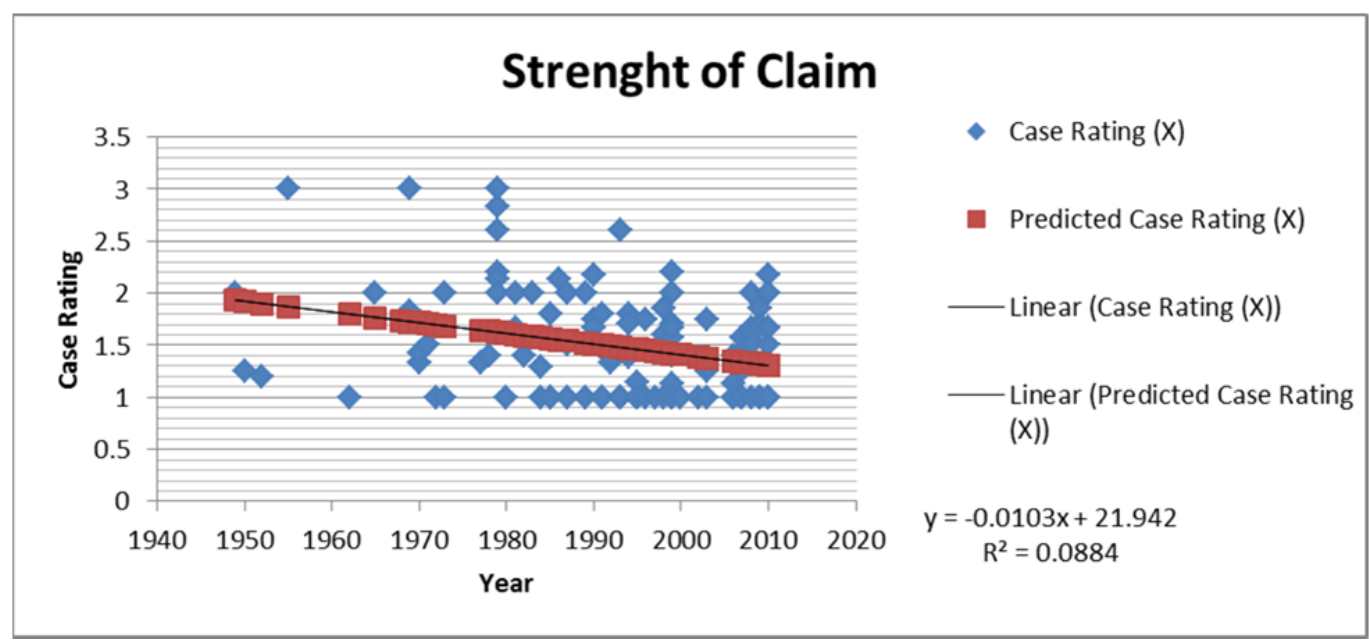

The strength of the claim brought by the plaintiff is declining. Statistically, this is well supported by regression analysis. In this case, where $\mathrm{Y}=-0.0103 \mathrm{x}+$ 21.942. That is, there is strong statistical evidence that indicates the strength of the plaintiffs' claims is weakening over time. Here, with a p value of 0.001 , we can say with $99 \%$ certainty that the relative strength of trademark claims has dimin-

away on its own, I would not support changing the law to be responsive to bullying. 
ished over time. That is, the regression analysis for the strength of trademark produced favorable results for the hypothesis that trademark strength in trademark bullying cases is declining. We also can predict that, with no additional variables, the strength of the claim will continue to decrease.

This regression analysis also tells us that the relative strength of a trademark claim is predicted to decrease in quality of 0.01 each year based on a case rating scale from $1-3$. For instance, if in the year 2000 the average strength of a claim where summary judgment was found in favor of defendant equals 1.342, then in 2001 we can expect that the strength of claim will equal 1.332. In one year, the strength of a claim is projected to fall $3 / 4$ of one percent. That is, the quality of the plaintiff's claim will continue to diminish.

\section{Degree of Similarity}

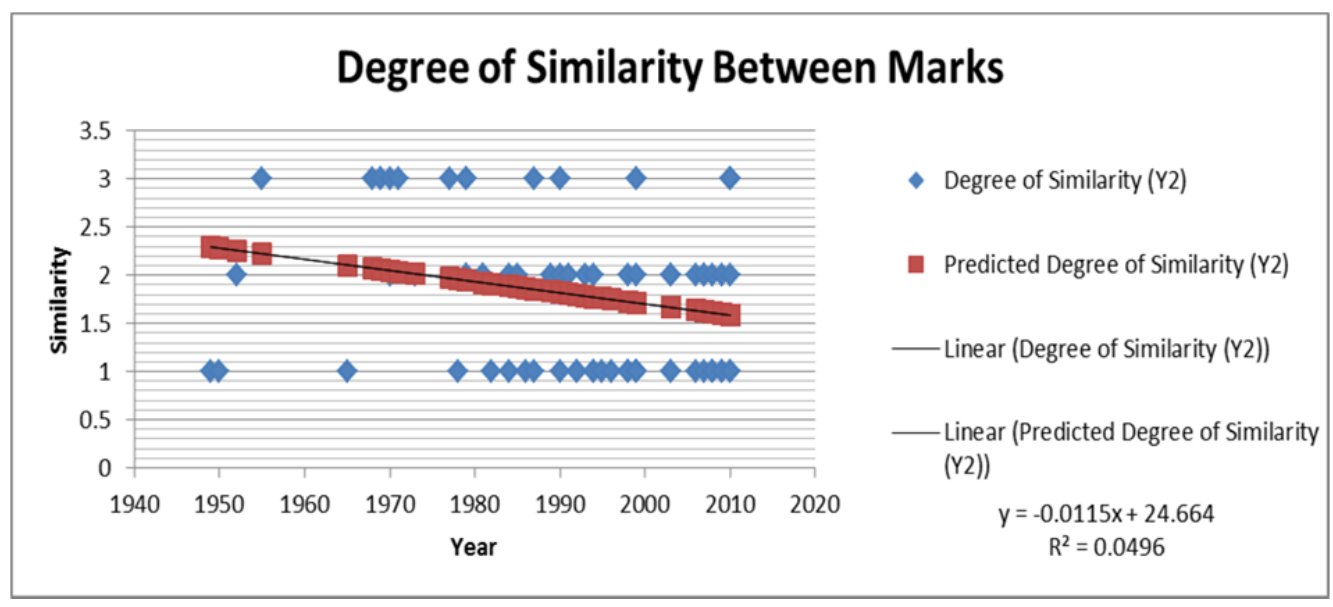

The degree of similarity between the plaintiff's mark and the defendant's mark has decreased since the inception of the Lanham Act in cases where the defendant prevailed in a motion for a summary judgment, that is, when trademark bullying was present. This is statistically portrayed above and this conclusion is also quite accurate. $\mathrm{Y}=-0.0115 \mathrm{x}+24.664$ [t stat $=-1.98 / \mathrm{p}$ value $=0.052$ ]. That is, the regression analysis for the degree of similarity between marks produced favorable results. We know with $94.98 \%$ certainty that the degree of similarity between a plaintiff and an allegedly infringing mark has diminished since 1949. The graph above describes this relationship. Where trademark bullying is likely, plaintiffs' marks are becoming more and more dissimilar to defendants' marks and this trend seems to be continuing.

1.

\section{Distinctiveness of Plaintiffs’ Marks}




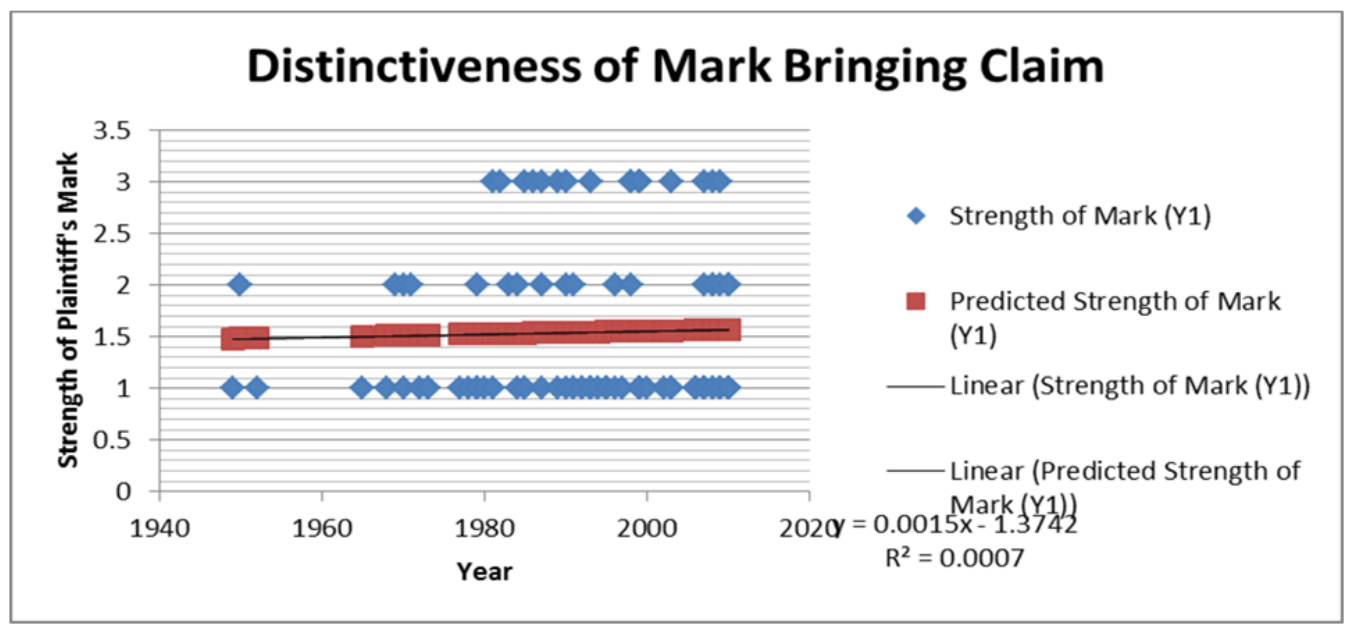

Here, the regression analysis did not support the contention that plaintiff's trademarks, in general, were generally becoming weaker and less distinctive. Where the p-value is 0.80 , no correlation can be said to exist.

The data does show, however, an interesting trend that in fact does support the contention that plaintiff's marks are becoming weaker. Specifically, of percentage of cases where summary judgment was found for defendant, it became increasingly rare for a plaintiff to assert rights in connection with an inherently distinctive mark. That is, from 1980 - 1990 there were six (6) inherently distinctive marks (of 16 cases); from 1990 - 2000, there were nine (9) inherently distinctive marks (of 40 cases); and, from 2000 - 2010, there were only four (4) inherently distinctive marks (of 40 cases).

During the period from 1980 - 1990, 38\% of cases where summary judgment was found for defendant involved inherently distinctive marks; from 1990 - 2000, $23 \%$; and, from $2000-2010$, only $10 \%$. Although the regression analysis does not support the contention that distinctiveness is declining over time, a simple consideration of the percentages of cases involved, demonstratively, does support such a hypothesis.

Therefore, it is safe to say that the distinctiveness of the plaintiff's marks in trademark bullying cases is in a declining trend. Fewer marks being used to enforce rights against trademark defendants are distinctive marks.

\section{Proximity of Goods or Services}

As with the distinctiveness of plaintiffs' marks, the regression analysis does not support the hypothesis that the goods or services of the plaintiffs is becoming more remote from defendants in cases of likely trademark bullying. This is most 
likely because there are excluded and unknown variables such as the expansion of the economy, diversity of products, etc. ${ }^{46}$

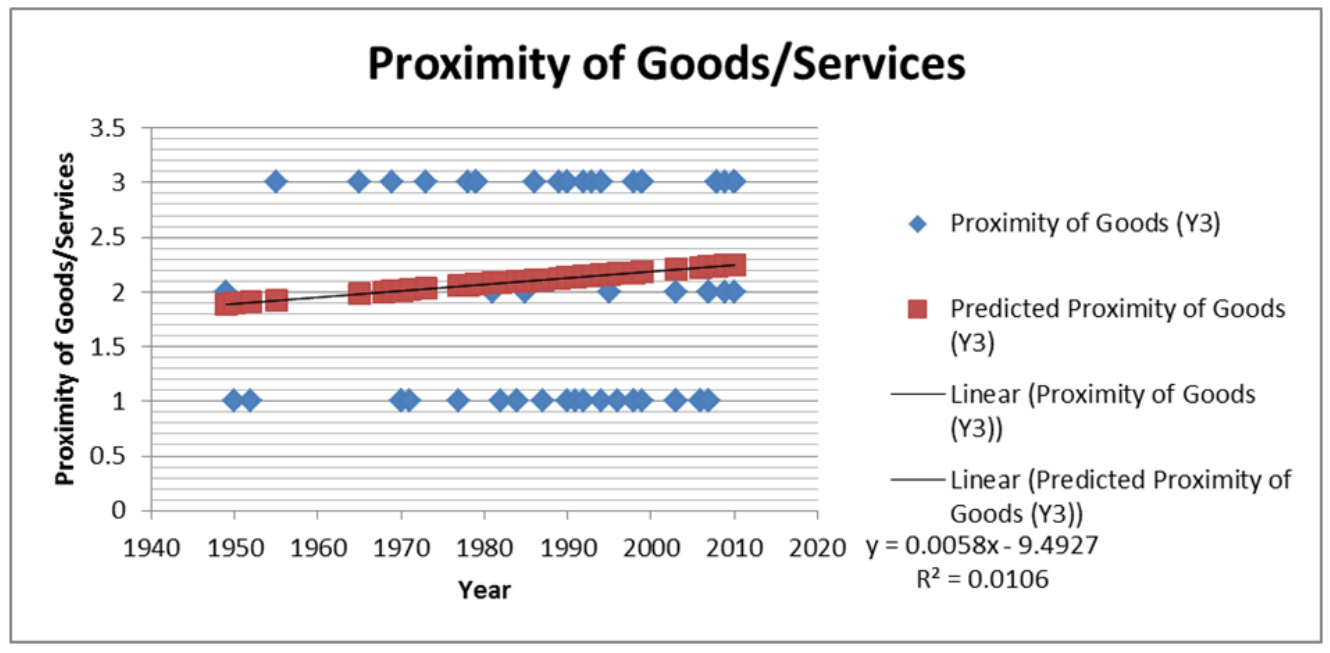

\section{MethodOLOGY}

The methodology for this study was time consuming but quite simple. I relied on the database I created for the Trademark Extortion article that I still maintain. This database lists all reported trademark cases in the United States that came to a dispositive result. It can be found at http:/web.wmitchell.edu/intellectualproperty/the-mitchell-study-on-trademark-litigation/. The database currently reports 2,972 trademark cases.

Of the 2,972 cases which had previously been coded for, among other things, the procedural posture of the case, I merely culled only those that reported the results of a summary judgment motion. Of course, these could have been complete summary judgment or partial summary judgment. I did not code for this distinction. I discovered 119 reported cases since the inception date of the Lanham Act, July 5, 1949, that involved a summary judgment motions.

Even though I did not code for the distinction between partial and complete summary judgment motions, to be included in the study, all cases had to come to a dispositive result terminating the case. Therefore, each of the 119 cases came to a dispositive result terminating the case or that issue in the case, but it is possible that another trademark-related or other cause of action permitted the case to proceed. In each of the 119 cases, at least one trademark-related cause of action was met with a summary judgment where the defendant prevailed.

Those 119 cases were then read and coded for the strength of the case. The strength of the case was determined by applying the Polaroid factors. Each case was coded 1-3 as to the likelihood that the plaintiff would prevail on the merits. Each case was read and given a score that reported its likelihood of success, one

46. Leah Chan Grinvald, Shaming Trademark Bullies, 2011 WISC. L. REV. 625, 634 (2011). 
factor at a time. In the end, each case received a score of 1-3 where 1 was extremely unlikely and 3 was extremely likely that the plaintiff would succeed on the merits.

Obviously, this part of the study was extremely arbitrary and subjective, however, it was consistently arbitrary and/or subjective. Two students read each case and determined what level of strength the case had; difficult cases were adjudicated by me. Therefore, although subjective, it is consistent in its outcome. Collectively, one set of eyes made every judgment as to how to score the strength of each case. Therefore, although subjective, the results were consistent.

All cases were then tabulated and presented in the graphs as shown above.

\section{SIGNIFICANCE}

The significance of this study is hard to overstate. In the battle over whether trademark bullying happens or not and, if so, how often, this study provides conclusive evidence that it is happening and it is a growing issue. If summary judgments in favor of the defendant are indicative of trademark bullying, trademark bullying happens in 5.5\% of the reported cases in the last decade.

The context for the number 5.5 is also startling. In $5.5 \%$ of the reported cases, money damages are awarded to the plaintiff. Therefore, trademark bullying is as meaningful to trademark jurisprudence as money damages.

This study is limited by the fact that it relies exclusively on reported cases where the defendant prevailed in its motion for summary judgment. Anecdotally, it is not hard to imagine many other cases where the defendant loses its motion for summary judgment. This could be because the plaintiff's case was stronger, material facts were unresolved, or the individual judge rarely granted summary judgments to defendants because he/she believed that every plaintiff deserves its day in court, etc. This study does not address the multiple reasons why a motion for a summary judgment by defendant might be denied. However, to be sure, many are denied. At least some of them might reasonably be considered to be part of this study but, because the judge denied the motion, it is not.

That is, $5.5 \%$ is a floor. Trademark bullying happens at least $5.5 \%$ of the time.

Also not considered in this study are all the times a defendant and victim of bullying simply ceases use of the mark and/or changes to a different mark. All of those instances are not captured in this study. Therefore, all the unreported cases where Party X sends Party Y a cease and desist letter and Party Y capitulates and stops using the mark or changes the mark are not part of this study. It may be that some or all or some percentage of all the Party Ys in the United States may have prevailed in a motion for summary judgment; however, because they capitulated, we will never know.

As there is no reporting requirement or registration system in the United States to publicize when a party sends or receives a cease and desist letter and the results, it is impossible to conclude how often this type of scenario happens. However, to be sure, it is not never. Therefore, $5.5 \%$ is a floor. Trademark bullying happens at least $5.5 \%$ of the time.

This is the primary finding of this study. I respectfully disagree with claims made by such authors as Vogel and Schachter based on no data whatsoever that 
bullying is best dealt with by existing law, that as sanctions such as Rule 11 are available to defendants, no action is required by Congress to respond to trademark bullying, even if it does exist. However, in the 119 cases where the defendant succeeded in its motion for summary judgment, the most egregious case possible where the court dismissed the plaintiff's case or cause of action with no regard for its rights to a day in court, Rule 11 sanctions were awarded in a total of zero cases. In fact, Rule 11 sanctions are very rarely awarded at all. To posit that because a theoretical sanction exists, there should be no concern about the actual conduct that could lead to the sanction is particularly empty when the sanction is never awarded.

\section{CONCLUSION}

Trademark bullying (a.k.a. trademark extortion) happens in 5.5\% of the reported cases. This is the same rate that plaintiffs recover any money damages. In the reported cases, trademark bullying is as significant, relevant and worrisome as cases where the plaintiff recovers money damages. Also, $5.5 \%$ is a floor. Trademark bullying happens at least $5.5 \%$ of the time. Where the ceiling is cannot be told because there is no requirement in the United States to report or record the sending out of cease and desist letters or how many times a trademark holder files suit to enforce its marks. Microsoft self-reports that they filed 235 law suits from 2001-2005. ${ }^{47}$ However, nowhere are the results recorded, maintained or analyzed.

The people that are not troubled by trademark bullying do not see evidence of it and therefore are not concerned. As there is no reporting or recording requirement in the United States, trademark bullying, if it happens at all, can only be found if we use deductive reasoning. This article is based on the deductive notion that cases where summary judgment was granted for the defendant are likely to represent cases of trademark bullying.

In trademark bullying cases, the quality of the plaintiff's claim is declining. This conclusion is supported by regression analysis that indicates that it is accurate to over $99 \%$ certainty.

Trademark bullying cases are increasing. Today, 5.5\% of the reported cases are likely bullying cases.

In trademark bullying cases, the degree of similarity between the marks at issue has decreased over time and continues to decrease.

In trademark bullying cases, the pace of growth of all reported trademark cases during the life of the Lanham Act has grown 2.91 times while the pace of growth whether the defendant prevailed in a summer judgment motion has grown at 8 times. That is, the growth rate of trademark bullying cases far exceeds the growth rate of general trademark infringement cases at large.

As no data (just suppositions) was provided by Vogel and Schachter, it is difficult to claim they are wrong in their analysis. Of course, Rule 11 and the other potential sanctions do exist. Without knowing how often they are used in cases

47. Michael Barbaro \& Julie Creswell, Levi’s Turns to Suing Its Rivals, N.Y. TiMES, Jan. 29, 2007, at A1 (claiming that Microsoft filed 235 infringement law suits from 2001-2006), available at http://www.nytimes.com/2007/01/29/business/29jeans.html. 
that manifest trademark bullying, it is impossible to take issue with their nonanalysis. Further, no data is relied on by the various trade organizations (simply outdated dicta from now ancient cases). The data here is the first attempt to prove or disproved trademark bullying. It is provided in the spirit of an academic inquiry. To me, the data here supports the idea that trademark bullying deserves the scrutiny that would be brought to bear if Congress elected to get involved. Clearly, the existing "safeguards" have been proven here to be anything but safe.

As such, Congress should act. Congress could go a long way in stopping trademark bullying if it amended Section 1117 of the Lanham to make it explicit that trademark infringement defendants as well as plaintiffs should be awarded its attorney's fees when the opposing party acts egregiously. Attorney's fees should be liberally awarded in cases where the defendant moves for summary judgment and prevails as these cases are the clearest manifestation of trademark bullying. 